Méthode : recension systématique des vocables rundi concernant les structures culturelles (matérielle, sociale, politique, intellecutelle). Dans chaque chapitre, à partir du vocable: $I^{\circ}$ exposé synthétique de la réalité culutrelle; $2^{\circ}$ vocabulaire idéologique; $3^{\circ}$ citation d'exemples avec référence aux textes traditionnels; $4^{\circ}$ références aux textes modernes rundi; $5^{\circ}$ considérations sur la psychologie et l'éthique rundi.

Présentation: l'analyse des structure culturelles sera traitée d'une part, et d'autre part, l'ensemble des textes de style oral rundi traditionnel formera un corpus justificatif séparé.

(Communication de F. M. Rodegem, p.b., Faculté des Sciences, Université Officielle de Bujumbura)

\title{
Recent Research in Sukumaland, Tanzania
}

A sTUDY is being prepared for publication under the direction and editorship of Gottfried $O$. Lang and Peter F. M. McLoughlin on progress among the Sukuma of Tanzania, who occupy some 20,000 square miles east and south of Lake Victoria, own approximately one-fifth of Tanzania's livestock, and produce most of the country's cotton, the second largest export by value. The study will pay particular attention to factors responsible for economic, social, and political changes in Sukumaland, and also to those which have precluded or delayed change. Development experience will be analysed so that current and future policies and procedures may profit from more precise definitions of trends, problems, and prospects. The contributors all have recent field experience in Sukumaland and are drawn from the disciplines of geography, economics, agricultural economics, anthropology, political science, sociology, and history. Coming from East Africa, Europe, and North America, most of them met with the editors in October 1965 and May 1966: a final meeting in October 1966 (at the A.S.A. meetings in Bloomington, Indiana) will permit mutual discussion of drafts. These meetings have benefited from African Studies Association (U.S.) financial assistance.

(Communicated by Peter F. M. McLoughlin)

\section{Project for Research on African Economic Systems by Dr. C. Meillassoux}

Trrs project is the continuation of research undertaken since 1958 on the economics of African societies (C. Meillassoux, 'Essai d'interprétation des phénomènes économiques dans les sociétés traditionnelles d'auto-subsistance', Cahiers d'Études Africaines, ig6o, no. 4, pp. 38-67). It will attempt to refine and clarify the structures and processes of economic systems found in pre- and post-colonial Africa; the social organization linked to each system; the conditions for equilibrium; the process of change in each system as an effect of contact; the compatibility and incompatibility of systems among themselves, etc. A choice among the cases available will be made on the basis of a provisional typology. Analysis of the modern and early works related to those selected will be undertaken. The construction of theoretical working models, applicable to the various systems, will be attempted for the discovery and explanation of the possible evolution of the economies, their capacity to resist, to adapt to, or be absorbed by other systems. The study will be both an attempt at the theoretization of the economic and social history of Africa and the basis for a theory of underdevelopment.

The history of Africa can be divided into four main periods: (I) period of relations of independent African societies among themselves, and of external trade relations, on the edges of the continent; (2) period of European slave trade; (3) colonial period; (4) period of emergence of new African states.

The basic economic systems emerged during the first period and have either lasted-more or less altered-until now, or have contributed to the societies that existed at the time of 